\title{
Physicochemical, phytochemical, and GC-MS analysis of leaf and fruit of Pouteria campechiana (Kunth) Baehni
}

\author{
Akshata Pai, Chandrakala Shenoy* \\ Department of Biosciences, Mangalore University, Mangalagangothri, India
}

ARTICLE INFO

Article history:

Received on: March 26, 2020

Accepted on: May 21, 2020

Available online: July 30, 2020

\section{Key words:}

Pouteria campechiana, physicochemical parameters, phytochemical screening, GC-MS analysis

\begin{abstract}
Medicinal plants have been used to treat various illnesses for decades. The present study supports the physicochemical, phytochemical, and gas chromatography-mass spectrometry (GC-MS) analysis of the methanolic extract of Pouteria campechiana leaves and fruits, in order to propose that the bona fide plant material is suitably for traditional use. The physicochemical evaluations and fluorescence analysis were determined according to standard protocols. The phytochemical constituents were carried out by both qualitative and quantitative methods. The GC-MS analysis was carried out to identify the compounds present. The physicochemical parameters revealed that the total ash content of $P$. campechiana leaves is more than the fruit. The water-soluble ash value of $P$. campechiana leaves is less than the acid-soluble ash value of the leaf, but the water-soluble ash value of $P$. campechiana fruit is greater than the acid-soluble ash value of the fruit. The water-extractive value of $P$. campechiana leaves and fruit is better when compared to the alcohol-extractive value. Moisture content, swelling index, and foaming index were found to be greater in the leaves than the fruit. Preliminary phytochemical screening showed the presence of various phytoconstituents. Quantitative analysis revealed that the leaf extract consists of high phenolic compounds followed by total flavonoids and total tannin than the fruit extract. The total alkaloid was found to be higher in the fruit extract than the leaf extract. Energy dispersive X-ray spectrometer analysis of the leaves showed the presence of elements such as $\mathrm{N}, \mathrm{O}, \mathrm{Cl}, \mathrm{K}, \mathrm{Ca}$, and $\mathrm{C}$ and fruits showed the presence of $\mathrm{N}, \mathrm{O}, \mathrm{K}$, and $\mathrm{C}$. The GC-MS analysis of $P$. campechiana leaf and fruit reveals the presence of 9 and 12 compounds, respectively. The results of the present study provide apparent information of the plant and also serve as an analytical tool for appropriate identification. Hence, this plant exhibits rich phytopharmaceutical importance.
\end{abstract}

\section{INTRODUCTION}

Since ancient times, herbs have been used as medicine for healing diseases and it has become a part of a culture of various peoples. Phytochemicals present in plants allow them to be used as medicinal plants. As a result, worldwide demands increased for medicinal plants and their pharmaceutical products. Therefore, the World Health Organization (WHO) has prescribed that it is essential for herbal products to undergo quality control tests for the purpose of potency and safety. Quality control is based on identity, purity, and other chemical, physical, and/or biological properties, as well as the manufacturing process [1]. The evaluation of physicochemical and phytochemical parameters helps in the identification,

\footnotetext{
*Corresponding Author

Chandrakala Shenoy, Department of Biosciences, Mangalore University, Mangalagangothri, India. E-mail: chandrakalashenoy2020@gmail.com
}

authentication, and safety of medicinal plants [2]. Phytochemical screening isolates various phytoconstituents present in plants for assessing their biological activity or medicinal uses. The medicinal value of plants is due to the definite physiological action of chemical substances on the living system [3].

Chan-Zapata et al. [4] described that the Pouteria campechiana (commonly known as canistel or egg fruit) belongs to the family Sapotaceae. The unripened fruit appears green in color and is hard with sticky pulp. The fruit is smooth and glossy in appearance upon ripening with a pale orange-yellow color and russet-colored patches. The fruit can be eaten raw or after baking and is also used to make various food items, such as ice creams, milkshakes, jam, and marmalade [5]. In traditional medicine, various parts of $P$. campechiana are used to heal various ailments. The bark and seeds are used to cure fevers, skin eruptions, and ulcers [4]. 
From a literature review, it was found that the $P$. campechiana possesses several pharmacological properties, such as antioxidant, antiinflammatory, antipyretic, and hepatoprotective properties [6]. The Pouteria species was reported to have many biologically active polyphenolic antioxidants, such as gallic acid, $(+)$-gallocatechin, $(+)$-catechin, (-)-epicatechin, dihydromyricetin, (+)-catechin-3O-gallate, and myricitrin [5].

Therefore, the present study aims to carry out the physicochemical, phytochemical, and gas chromatography-mass spectrometry (GCMS) analysis of the methanolic extract of $P$. campechiana leaves and fruits to ascertain the chemical standards and constituents, in order to identify and authenticate the plant material for future use.

\section{MATERIALS AND METHODS}

The leaves and fruits of $P$. campechiana were collected from Bellikoth, Kasargod District, Kerala. The plant material was identified and authenticated in the Department of Botany, Kerala University, Kariavattom. The voucher specimens were preserved in the botany department herbarium library (accession no: KUBH 10170).

\subsection{Sample Collection and Processing}

The fresh leaves and fruits of the plants were collected, cleaned well by washing twice with distilled water, and shade dried for about 5 weeks and 20 weeks, respectively, at an ambient temperature of $30^{\circ} \mathrm{C}$. Dried leaf and fruit materials were then subjected to pulverization to obtain coarse powder, which was stored at room temperature for further studies.

\subsection{Physicochemical Standardization}

The standardization of the $P$. campechiana leaves and fruits powder was carried out in accordance with the WHO guidelines and procedures listed in the Indian pharmacopeia [7]. The standardization studies on different physicochemical parameters, including moisture content, water- and alcohol-soluble extracts, swelling index, foaming index, foreign matter, $\mathrm{pH}$, ash values, were carried out.

\subsection{Fluorescence Analysis}

Fluorescence analysis of the plant material was carried out according to the methods of Chase and Pratt [8]. About $1 \mathrm{~g}$ of powdered leaves and fruits of $P$. campechiana was taken in clean and dried test tubes. About $5 \mathrm{ml}$ of different organic solvents, like methanol, chloroform, ethanol, diethyl ether, petroleum ether, acetone, benzene, glacial acetic acid, sulphuric acid, hydrochloric acid, nitric acid, In sodium hydroxide, and distilled water, were added separately to each tube. Then, all the tubes were mixed well and were allowed to stand for about 20-25 minutes for the color to develop and the solutions obtained and recorded were observed under the visible and UV light for their characteristic colour reaction.

\subsection{Preliminary Phytochemical Screening}

\subsubsection{Preparation of plant extract}

Powdered leaves $(180 \mathrm{~g})$ and fruits $(70 \mathrm{~g})$ of $P$. campechiana were used for extraction. The extraction was carried out by the continuous hot percolation method in a Soxhlet apparatus using methanol. The extracts thus obtained were concentrated by removal of the solvent using the rotary vacuum evaporator and then dried and stored in airtight bottles in a refrigerator at $4^{\circ} \mathrm{C}$ for further use. The percentage extractive yields of the methanolic extract of leaves and fruits were recorded.

\subsubsection{Qualitative phytochemical analysis}

The extracts prepared were analyzed for the presence of alkaloids, glycosides, tannins, flavonoids, fixed oils, steroids, phenols, quinones, anthraquinones, lignins, resins, saponins, coumarins, proteins, and carbohydrates as per standard protocols [9-13].

\subsection{Quantitative Phytochemical Analysis}

2.5.1, Estimation of total phenolic content (TPC)The TPC of the methanolic extract of leaves and fruits of plant was carried out by Folin-Ciocalteu's assay with minute modifications [14]. Gallic acid was used as a standard. About $1 \mathrm{ml}$ of standard solution of different concentrations $(10-100 \mu \mathrm{g} / \mathrm{ml})$ of gallic acid was prepared in methanol. The sample $(1 \mathrm{mg} / \mathrm{ml})$ was also prepared in methanol, and $0.5 \mathrm{ml}$ of each sample was taken in test tubes and mixed with $2.5 \mathrm{ml}$ of $10 \%$ Folin-Ciocalteu's phenol reagent. After 5 minutes, $7.5 \%$ sodium carbonate solution $(2 \mathrm{ml})$ was added to the mixture and mixed well. The mixture was kept for 30 minutes in the dark at an ambient temperature. The absorbance of the resulting blue color solution was read at $760 \mathrm{~nm}$ spectrometrically. The TPC was expressed as milligrams of gallic acid equivalents (GAE)/g of dried sample.

\subsubsection{Estimation of total flavonoids content}

The total flavonoid content in the sample was estimated by the aluminum chloride method, with slight modification [14]. In this method, quercetin was used as the standard. About $1 \mathrm{ml}$ of the standard $(1 \mathrm{mg} / \mathrm{ml})$ of different concentrations $(20-500 \mu \mathrm{g} /$ $\mathrm{ml})$ and $1 \mathrm{ml}$ of the extract $(1 \mathrm{mg} / \mathrm{ml})$ were taken in a $10-\mathrm{ml}$ volumetric flask containing distilled water (4 ml). About 5\% $\mathrm{NaNO}_{2}(0.3 \mathrm{ml})$ was added to the flask. After 5 minutes, $10 \%$ $\mathrm{AlCl}_{3}(0.3 \mathrm{ml})$ and $1 \mathrm{M} \mathrm{NaOH}(2 \mathrm{ml})$ was added, and to make the volume $10 \mathrm{ml}, 3.4 \mathrm{ml}$ distilled water was added. The solution was stirred and the absorbance was noted at $510 \mathrm{~nm}$ along with the standard quercetin using UV-visible spectrophotometer. The results are expressed as $\mathrm{mg}$ of flavonoids as quercetin equivalent/g of dried sample.

\subsubsection{Estimation of alkaloids}

About $5 \mathrm{~g}$ of the sample was taken in a beaker and $10 \%$ acetic acid in ethanol $(200 \mathrm{ml})$ was added to it. The mixture was covered and allowed to stand for 4 hours. After incubation, the mixture was filtered and the filtrate was concentrated on a water bath at $100^{\circ} \mathrm{C}$, until the original volume of filtrate reduced to one-quarter. Concentrated ammonium hydroxide was added dropwise to the extract until precipitation was completed. To collect the precipitate, the solution was allowed to settle down. Using diluted ammonium hydroxide, the precipitate was washed and filtered. The alkaloid residue obtained was dried and weighed [15]. 


\subsubsection{Estimation of total tannin content}

The tannins were determined by Folin-Ciocalteu's method with little modification [16]. About $1 \mathrm{ml}$ of the sample extract $(1 \mathrm{mg} /$ $\mathrm{ml})$ was added to a volumetric flask $(10 \mathrm{ml})$ containing distilled water $(7.5 \mathrm{ml})$, Folin-Ciocalteu's phenol reagent $(0.5 \mathrm{ml})$, and $35 \%$ sodium carbonate solution $(1 \mathrm{ml})$, and distilled water added to make to the volume $10 \mathrm{ml}$. The mixture was mixed thoroughly and kept at room temperature for 30 minutes. The tannic acid (1 mg/ $\mathrm{ml}$ ) was used as the reference standard. Different concentrations of tannic acid $(10-150 \mu \mathrm{g} / \mathrm{ml})$ were prepared in the same manner which serves as the standard. Absorbance was measured at 700 $\mathrm{nm}$ against the blank. The tannin content was expressed in terms of $\mathrm{mg}$ of tannic acid equivalents/g of dried sample.

\subsection{GC-MS Analysis}

The GC-MS analysis of the methanolic extract of leaves and fruits of $P$. campechiana was carried out using a GC-MS model (QP 2010 Plus, Shimadzu). The instrument contained Rxi-5Sil MSfused silica capillary column of $30-\mathrm{m}$ length, $0.25-\mathrm{mm}$ diameter, $0.25-\mu \mathrm{m}$ film thickness, column oven with temperature ranges from $80.0^{\circ} \mathrm{C}$ to $280^{\circ} \mathrm{C}$, and the injector temperature was $260.00^{\circ} \mathrm{C}$. The carrier gas (Helium: $99.9995 \%$ purity) was secured with a column flow rate of $1 \mathrm{ml} / \mathrm{minute}$. The mass ranges from 50 to 500 $\mathrm{m} / \mathrm{z}$ were scanned at a rate of 1,000 scans $/ 0.50$ seconds. Manually, using Hamilton's syringe, $1.0 \mu \mathrm{l}$ of methanolic extract of the leaf and fruit was injected (split injection technique) for analysis. The relative percentage of constituents present in the methanolic extract was expressed as percentage with peak area normalization. The bioactive compounds present in the methanol extract were identified by comparing the retention time and patterns of mass peak with reference to the Wiley Registry of Mass Spectral Data, New York (Wiley8) and the database of the National Institute Standard and Technology (NIST) 11 [17].

\subsection{Energy Dispersive X-Ray Spectrometer (EDS) Analysis}

The partial quantification elemental analyses were carried out using OXFORD INCA EDS to identify the weight percentage of elements (major and minor) present in the samples.

\subsection{Statistical Analysis}

Values have been expressed as mean \pm standard deviation ( $n$ $=3$ ) and comparison of physicochemical and phytochemical parameters of $P$. campechiana leaf and fruit was evaluated by applying Student's $t$-test.

\section{RESULTS}

\subsection{Physicochemical Standardization}

All the physicochemical standards values are an average of three determinations (Table 1). The physicochemical parameters revealed that the total ash content of $P$. campechiana leaves is more than the fruit $(p<0.0001$, Student's $t$-test). The watersoluble ash value of $P$. campechiana leaves is less than the acidsoluble ash value of leaves, but the water-soluble ash value of $P$. campechiana fruit is greater than the acid-soluble ash value of the fruit. The water-extractive value of $P$. campechiana leaves and fruits is better when compared to the alcohol-extractive value ( $p$ $<0.0001$, Student $t$-test). Moisture content, swelling index, and foaming index were found to be greater in leaves than fruits.

\subsection{Fluorescence Analysis}

The powder was suspended with various chemical reagents and the fluorescence nature was observed and recorded by comparing the color developed in day light and UV (312 nm) light (Table 2).

\subsection{Extractive Yield}

The percentage yields of the methanolic extract of leaves and fruits were found to be $13.44 \%$ and $29.68 \%$, respectively.

\subsection{Qualitative Phytochemical Analysis}

The extracts were subjected to preliminary phytochemical screening to identify the phytoconstituents present in the plant extract using chemical reagents. The phytochemical tests of the methanolic extract of leaf and fruit revealed the presence of phytoconstituents, such as alkaloids, glycosides, tannin, flavonoids, fats and fixed oils, steroid, phenols, quinone, lignin, resin, carbohydrate and protein, and absence of saponin.

\subsection{Quantitative Phytochemical Analysis}

Based upon the preliminary phytochemical analysis, quantitative estimation of phytoconstituents was carried out by various standard methods. The results of total phenolic, flavonoid, alkaloid, and tannin contents are presented in Table 3. $P$. campechiana leaf extract showed a higher amount of total phenol content, total tannin content, and flavonoid content than the fruit extract ( $p<0.0001$, Student $t$-test). Total alkaloid was found to be higher in the fruit extract than the leaf extract $(p<0.0021$, Student $t$-test).

\subsection{GC-MS Analysis}

The GC-MS chromatogram shows the presence of 9 compounds (Fig. 1) in the methanolic extract of the $P$. campechiana leaf and 12 compounds (Fig. 2) in the methanolic extract of the $P$. campechiana fruit. The results obtained were identified based on comparing the mass spectra with those of NIST and Wiley Libraries. The identified compounds and their retention time, molecular formula, molecular weight, and percentage peak area are presented in Tables 4 and 5 .

\subsection{EDS Analysis}

The Scanning electron microscope-energy dispersive spectrometer (SEM-EDX) spectra obtained for $P$. campechiana leaf and fruit powder are shown in Figures 3 and 4, while their elemental compositions are listed in Table 6.

\section{DISCUSSION}

Since $P$. campechiana has been used in traditional medicine to treat various ailments, it is essential to standardize the drug for use. The physicochemical parameters are important for detecting adulteration or improper handling of drugs [18]. The assessment of 
(Kunth) Baehni 2020;8(04):90-97

Table 1: Physicochemical standardization of leaves and fruits of $P$. campechiana

\begin{tabular}{|c|c|c|c|}
\hline SI. No. & Parameters & P. campechiana leaves (\%) & P. campechiana fruits $(\%)$ \\
\hline 1. & Moisture content & $6.477 \pm 0.422$ & $4.633 \pm 2.025^{\mathrm{ns}}$ \\
\hline 2. & Total ash & $7.646 \pm 0.096$ & $1.133 \pm 0.230^{* * * *}$ \\
\hline 3. & Acid insoluble ash & $0.326 \pm 0.282$ & $0.166 \pm 0.288^{\mathrm{ns}}$ \\
\hline 4. & Acid soluble ash & $7.286 \pm 0.275$ & $0.833 \pm 0.288^{* * *}$ \\
\hline 5. & Water insoluble ash & $5.5 \pm 1.322$ & $1 \pm 0$ \\
\hline 6. & Water soluble ash & $2 \pm 0.866$ & $1.333 \pm 0.288^{\mathrm{ns}}$ \\
\hline 7. & Sulphated ash & $11.42 \pm 0.034$ & $3.48 \pm 0.5^{* * * *}$ \\
\hline 8. & Water soluble extractives & $19.734 \pm 2.935$ & $56 \pm 3.464^{* * *}$ \\
\hline 9. & Alcohol soluble extractives & $16.813 \pm 0.965$ & $38 \pm 2.645^{* * *}$ \\
\hline 10. & Foaming index & $>100$ units \pm 0 & $<100$ units \\
\hline 11. & Swelling index & $4.466 \mathrm{ml} \pm 0.057$ & $3.466 \mathrm{ml} \pm 0.057^{* * *}$ \\
\hline 12. & Foreign matter & Nil & Nil \\
\hline 13. & $\mathrm{pH}$ & $5.426 \pm 0.050$ & $4.433 \pm 0.040^{* * * *}$ \\
\hline
\end{tabular}

The values represent 'Mean \pm SD' of three replicates. P. campechiana fruit versus $P$. campechiana leaf: ${ }^{* * *} p<0.0001{ }^{\text {ns }}=$ not significant (Student $t$-test).

Table 2: Fluorescence analysis of powdered leaves and fruits of $P$. campechiana.

\begin{tabular}{|c|c|c|c|c|}
\hline \multirow{2}{*}{ Powdered drug } & \multicolumn{2}{|c|}{ P. campechiana leaves } & \multicolumn{2}{|c|}{ P. campechiana fruits } \\
\hline & Visible/day light & UV (312 nm) & Visible/day light & UV (312 nm) \\
\hline Powder + Methanol & Light green & Pink & Yellow & Bluish green \\
\hline Powder + Chloroform & Dark green & Neon pink & Yellow & Bluish green \\
\hline Powder + Ethanol & Light green & Neon pink & Yellowish green & Bluish green \\
\hline Powder + Diethyl ether & Light green & Neon pink & Yellowish green & Bluish green \\
\hline Powder + Petroleum ether & venom green & Neon pink & Yellowish green & Bluish green \\
\hline Powder + Acetone & Light green & Neon pink & Yellow & Bluish green \\
\hline Powder + Benzene & Light brown & Neon pink & Yellowish green & Bluish green \\
\hline Powder + Glacial acetic acid & Brown & Neon pink & Yellowish green & Bluish green \\
\hline Powder + Sulphuric acid & Niger brown & Lavender bluish & Brown & Violet \\
\hline Powder + Hydrochloric acid & Niger brown & Lavender bluish & Black & Violet \\
\hline Powder + Nitric acid & Orange brown & Light purple & Pale yellow & Violet \\
\hline Powder $+1 \mathrm{~N} \mathrm{NaOH}$ & Brown & Light blue & Black & Violet \\
\hline Powder + Distilled water & Light orange & Light purple & Colourless & Bluish green \\
\hline
\end{tabular}

Table 3: Quantitative analysis of phytochemicals of leaves and fruits of $P$. campechiana.

\begin{tabular}{lcc} 
Phytochemical constituents & P. campechiana leaf & P. campechiana fruit \\
Total phenolic (mg/g) content (in GAE*) & $91.65 \pm 0.613$ & $6.026 \pm 0.109^{* * *}$ \\
Total flavonoid (mg/g) content (in QE*) & $377.77 \pm 4.811$ & $16.79 \pm 0.320^{* * *}$ \\
Total Alkaloids (\%) & $6.44 \pm 0.728$ & $10.50 \pm 0.674^{* *}$ \\
Total tannin (mg/g) content (in TAE*) & $167.02 \pm 0.196$ & $6.045 \pm 0.039^{* * *}$ \\
\hline
\end{tabular}

Results are mean of triplicate determinations based on the reference standard \pm standard deviation. $P$. campechiana fruit vs $P$. campechiana leaf: ${ }^{* *} p<0.0021{ }^{* * *}, p<0.0001$ (Student $t$-test). GAE = Gallic acid equivalent; $\mathrm{QE}=$ Quercetin equivalent; TAE $=$ Tannic acid equivalent.

the purity of drugs, i.e., the presence or absence of foreign organic matter, such as metallic salts and/or silica, mainly depends on the total ash present in the plant material [2]. The amount of inorganic elements is determined by water-soluble ash. In this study, the results of different types of ash values may provide a basis to identify the purity and quality of the drug. The low moisture content $(\%)$ of the leaf and fruit $(6.477 \pm 0.422,4.633 \pm 2.025)$ helps in reducing of the growth of bacteria, yeast, or fungi through storage. The assessment of the nature of powder can be identified by extractive value and also helps to assist in the evaluation of solubility of specific constituents in a particular solvent [2]. In the present study, the percentage extractive yields of leaf and fruit were higher in water $(19.73 \%$ and $56 \%$, respectively) than alcohol (16.81\% and $38 \%$, respectively), which signifies that the large amount of phytoconstituents of the aerial parts was soluble in water than alcohol.Fluorescence analysis is a rapid method for 


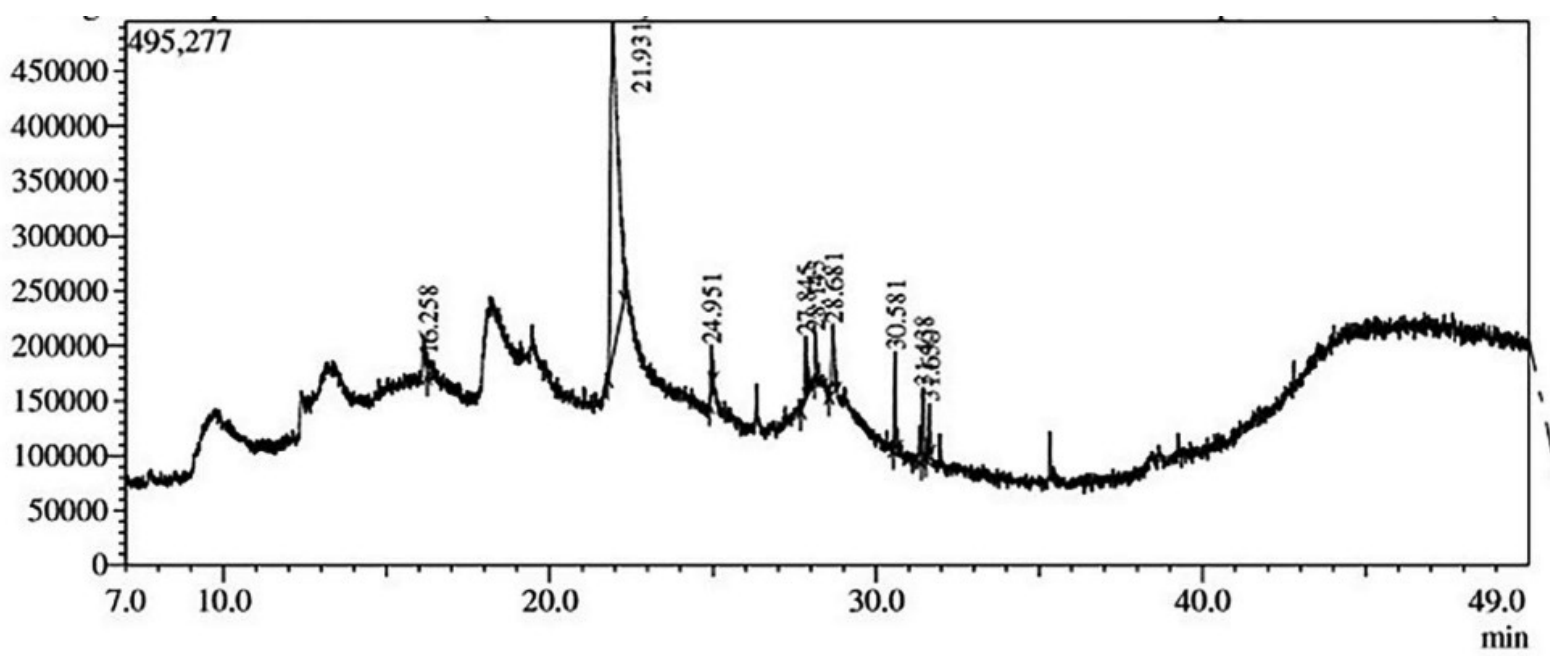

TIC*1.00

Figure 1: GC-MS chromatogram of the methanolic extract of $P$. campechiana leaf.

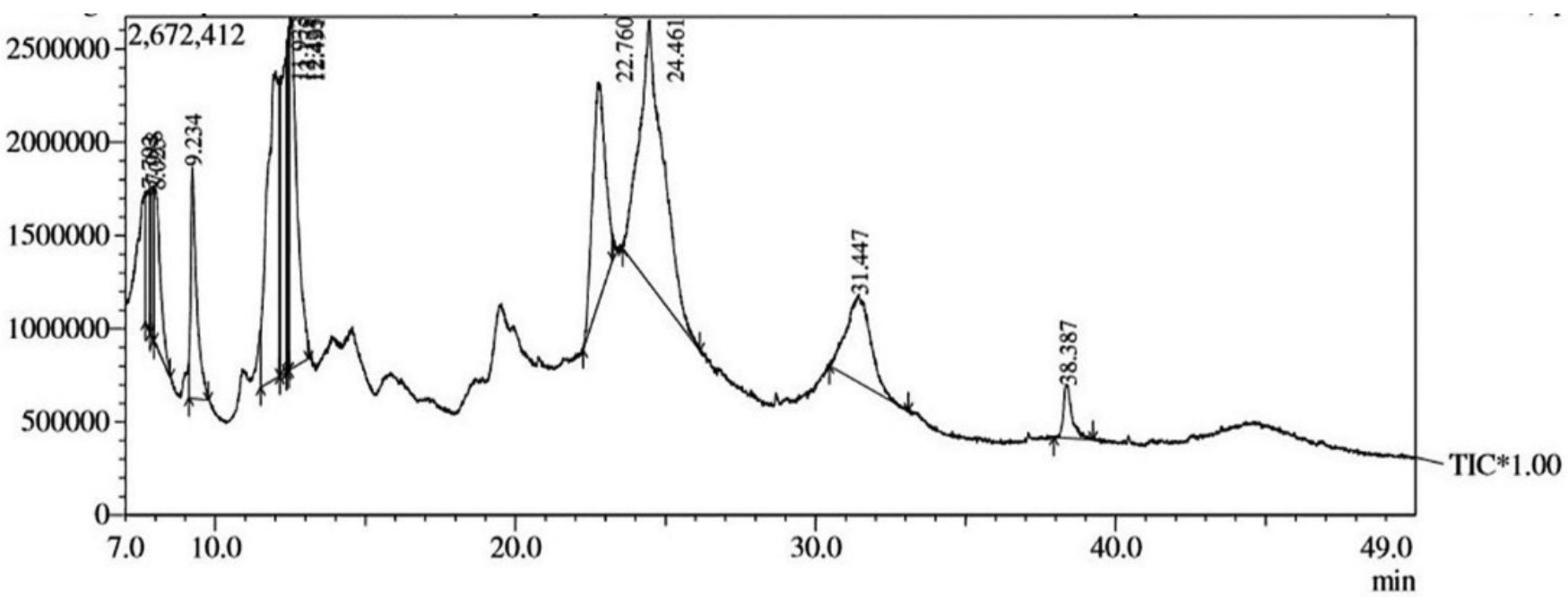

Figure 2: GC-MS chromatogram of the methanolic extract of $P$. campechiana fruit.

Table 4: Phytoconstituents identified in the methanolic extract of $P$. campechiana leaf by GC-MS analysis.

\begin{tabular}{|c|c|c|c|c|c|c|}
\hline Sl.no & R. Time & Compound name & Molecular formula & Mol. Wt & Peak area \% & Nature and its biological activity \\
\hline 1 & 16.258 & $\begin{array}{l}\text { N-(2-Cyano-Ethyl)-N-Methyl- } \\
\text { Acetamide }\end{array}$ & $\mathrm{C}_{4} \mathrm{H}_{6} \mathrm{~N}_{2} \mathrm{O}$ & $98.1 \mathrm{~g} / \mathrm{mol}$ & 2.10 & - \\
\hline 2 & 21.931 & Chinasaure & $\mathrm{C}_{7} \mathrm{H}_{12} \mathrm{O}_{6}$ & $192.17 \mathrm{~g} / \mathrm{mol}$ & 73.96 & astringent \\
\hline 3 & 24.951 & Calendin & $\mathrm{C}_{11} \mathrm{H}_{16} \mathrm{O}_{3}$ & $196.25 \mathrm{~g} / \mathrm{mol}$ & 2.15 & - \\
\hline 4 & 27.845 & Aspidocarpine & $\mathrm{C}_{22} \mathrm{H}_{30} \mathrm{~N}_{2} \mathrm{O}_{3}$ & $370.5 \mathrm{~g} / \mathrm{mol}$ & 4.21 & Alkaloid \\
\hline 5 & 28.143 & Octadecanoic acid, methyl ester & $\mathrm{C}_{19} \mathrm{H}_{38} \mathrm{O}_{2}$ & $298.5 \mathrm{~g} / \mathrm{mol}$ & 2.20 & $\begin{array}{l}\text { Fatty acid methyl ester } \\
\text { Antifungal, antibacterial, antimicrobial, emulsifier, } \\
\text { perfumery industry }\end{array}$ \\
\hline 6 & 28.681 & Dibutyl phthalate & $\mathrm{C}_{16} \mathrm{H}_{22} \mathrm{O}_{4}$ & $278.34 \mathrm{~g} / \mathrm{mol}$ & 5.31 & $\begin{array}{l}\text { Plasticizer compound } \\
\text { Antimicrobial, antifouling }\end{array}$ \\
\hline 7 & 30.581 & Kaur-16-ene & $\mathrm{C}_{20} \mathrm{H}_{32}$ & $272.5 \mathrm{~g} / \mathrm{mol}$ & 3.81 & - \\
\hline 8 & 31.438 & $\begin{array}{l}\text { 11,14,17- eicosatrienoic acid,methyl } \\
\text { ester }\end{array}$ & $\mathrm{C}_{21} \mathrm{H}_{36} \mathrm{O}_{2}$ & $320.5 \mathrm{~g} / \mathrm{mol}$ & 4.10 & $\begin{array}{l}\text { Unsaturated fatty acid ester } \\
\text { Antiarthritic, anticoronary, antiinflammatory }\end{array}$ \\
\hline 9 & 31.630 & Phytol, acetate & $\mathrm{C}_{22} \mathrm{H}_{42} \mathrm{O}_{2}$ & $338.6 \mathrm{~g} / \mathrm{mol}$ & 2.16 & Antioxidant, antimicrobial, anticancer, diuretic \\
\hline
\end{tabular}


(Kunth) Baehni 2020;8(04):90-97

Table 5: Phytocomponents identified in the methanolic extract of $P$. campechiana fruit by GC-MS analysis.

\begin{tabular}{|c|c|c|c|c|c|c|}
\hline Sl.no & R. Time & Compound name & Molecular formula & Mol. Wt & Peak area $\%$ & Nature and its biological activity \\
\hline 1 & 7.792 & Acetic acid, pentyl ester & $\mathrm{C} 7 \mathrm{H} 14 \mathrm{O} 2$ & $130.18 \mathrm{~g} / \mathrm{mol}$ & 2.45 & $\begin{array}{l}\text { Fatty acid ester } \\
\text { Metabolite }\end{array}$ \\
\hline 2 & 7.918 & Dimethylamine, N-(Neopentyloxy)- & $\mathrm{C} 7 \mathrm{H} 17 \mathrm{NO}$ & $131.22 \mathrm{~g} / \mathrm{mol}$ & 1.85 & - \\
\hline 3 & 8.025 & Glycerin & $\mathrm{C} 3 \mathrm{H} 8 \mathrm{O} 3$ & $92.09 \mathrm{~g} / \mathrm{mol}$ & 4.07 & $\begin{array}{l}\text { Alcohol } \\
\text { Antibacterial activity }\end{array}$ \\
\hline 4 & 9.234 & $\begin{array}{l}\text { 4H- Pyran-4-one, 2,3-Dihydro-3,5- } \\
\text { Dihydroxy-6-methyl- }\end{array}$ & $\mathrm{C}_{6} \mathrm{H}_{8} \mathrm{O}_{4}$ & $144.12 \mathrm{~g} / \mathrm{mol}$ & 5.65 & $\begin{array}{l}\text { Flavonoid fraction } \\
\text { Antimicrobial,antiinflammatory and } \\
\text { antioxidant }\end{array}$ \\
\hline 5 & 11.933 & 2-pentene, 3-ethyl-4,4-Dimethyl- & С9H18 & $126.24 \mathrm{~g} / \mathrm{mol}$ & 15.17 & - \\
\hline 6 & 12.175 & 5-keto-2,2-dimethylheptanimine & & & 7.69 & - \\
\hline 7 & 12.425 & $\begin{array}{l}\mathrm{N}, \mathrm{N} \text { - dimethyl-O-(1-methyl-butyl)- } \\
\text { hydroxylamine }\end{array}$ & $\mathrm{C} 7 \mathrm{H} 17 \mathrm{NO}$ & $131.22 \mathrm{~g} / \mathrm{mol}$ & 3.05 & - \\
\hline 8 & 12.491 & DL-Arabinitol & $\mathrm{C} 5 \mathrm{H} 12 \mathrm{O} 5$ & $152.15 \mathrm{~g} / \mathrm{mol}$ & 11.25 & $\begin{array}{l}\text { Sugar alcohol } \\
\text { Metabolite }\end{array}$ \\
\hline 9 & 22.760 & $\beta$-D-Glucopyranoside, methyl & C7H14O6 & $194.18 \mathrm{~g} / \mathrm{mol}$ & 11.76 & - \\
\hline 10 & 24.461 & 3-Deoxy-d-mannoic lactone & $\mathrm{C}_{6} \mathrm{H}_{10} \mathrm{O}_{5}$ & $162.14 \mathrm{~g} / \mathrm{mol}$ & 26.29 & $\begin{array}{l}\text { Cyclic ester } \\
\text { Antimicrobial activity }\end{array}$ \\
\hline 11 & 31.447 & d-Glycero-d-tallo-heptose & $\mathrm{C}_{7} \mathrm{H}_{14} \mathrm{O}_{7}$ & $210.18 \mathrm{~g} / \mathrm{mol}$ & 8.83 & sugars \\
\hline 12 & 38.387 & Stigmast-5-EN-3-OL, (3 $\beta)$ & $\mathrm{C} 29 \mathrm{H} 50 \mathrm{O}$ & $414.7 \mathrm{~g} / \mathrm{mol}$ & 1.93 & $\begin{array}{l}\text { Antiinflammatory, Antipyretic, Antiulcer, } \\
\text { Antiarthritic }\end{array}$ \\
\hline
\end{tabular}

resolution of doubtful specimen. When physical and chemical methods are insufficient, the plant material may be identified from their adulterants based on the fluorescence characteristics. Behaviors of the powdered drug with different chemical reagents and qualitative and quantitative phytochemical analyses are helpful for detecting various phytoconstituents [19].

The phytochemical analysis of the plant detected the presence of various phytoconstituents which are known to reveal medicinal use in addition to the action on the human body [20]. The presence of these secondary metabolites indicates that the plant might be of medicinal significance. Depending on the preliminary phytochemical test, quantitative determination of phytoconstituents was carried out by various standard methods. The total phenol contents were found to be higher $(91.65 \pm 0.613$ $\mathrm{mg}$ GAE/g) in $P$. campechiana leaf extract than fruit extract $(6.026 \pm 0.109 \mathrm{mg}$ GAE$/ \mathrm{g}) . P$. campechiana leaf extract showed a higher $[377.77 \pm 4.811 \mathrm{mg}$ Quercetin equivalent $(\mathrm{QE}) / \mathrm{g}]$ amount of flavonoid content and lower amount $(16.79 \pm 0.320 \mathrm{mg} \mathrm{QE} / \mathrm{g})$ in fruit extract. Total alkaloid was found to be higher $(10.50 \pm$ $0.674 \%)$ in fruit extract than in leaf extract $(6.44 \pm 0.728 \%)$. Total tannin content showed a higher amount (167.02 \pm 0.196 $\mathrm{mg}$ TAE/g) in leaf extract and lower amount $(6.045 \pm 0.039$ $\mathrm{mg} \mathrm{TAE} / \mathrm{g}$ ) in fruit extract. The qualitative and quantitative phytochemical investigations gave beneficial information and ideas about the different phytoconstituents present in the plant. These phytoconstituents possess a wide range of activities, which may be a defense against chronic diseases [20]. The tested plant reveals the presence of various phytochemicals, and quantitative analysis showed higher amount of flavonoids in both leaf and fruit when compared to other compounds. Flavonoids are considered as one of the most varied and prevalent group of natural compounds.
Many flavonoid compounds demonstrated to prevent injury caused by free radicals [2].

The chemical constituents of P.campechiana were characterized by the GC-MS analysis. Through GC-MS analysis, the phytoconstituents present in plants can be identified, and that gives a clear picture of the pharmaceutical value of the plant [17]. The GC-MS chromatogram shows the presence of various compounds in the methanolic extract of the $P$. campechiana leaf and fruit by comparing their retention times and by interpretation of their mass spectra of compound. The compounds identified in the crude methanol extract of the leaf are N-(2-cyano-ethyl)n-methyl-acetamide, chinasaure, calendin, aspidocarpine, octadecanoic acid methyl ester, dibutyl phthalate, kaur-16ene, 11,14,17-eicosatrienoic acid methyl ester, and phytol acetate. The compounds identified in the crude methanol extract of the fruit are acetic acid, pentyl ester, dimethylamine, $\mathrm{N}$-(NEopentyloxy), glycerin, 4H-Pyran-4-one, 2,3-dihydro3,5-dihydroxy-6-methyl, 2-pentene, 3-ethyl-4,4-dimethyl-, 5-keto-2,2-dimethylheptanimine, N,N-dimethyl-O-(1-methylbutyl) hydroxyl amine, DL-arabinitol, $\beta$-D-glucopyranoside methyl, 3-deoxy-d-mannoic lactone, d-glycero-d-tallo-heptose, and stigmast-5-en-3-ol, (3 $\beta$ ).Phytosterol, stigmast-5-en-3ol $(3 \beta)$ is involved in lowering cholesterol and stimulating glucose transport in vitro [21]. Phytol belongs to reactive oxygen species-promoting substances and is involved in curing rheumatoid arthritis and other chronic inflammatory diseases [2]. Octadecanoic acid methyl ester has both antibacterial and antifungal properties [22]. 3-Deoxy-d-mannoic lactone has been reported to have antibacterial activity. Glycerin decreases intracranial pressure and intraocular pressure in numerous disease states [23]. The biological property of other 

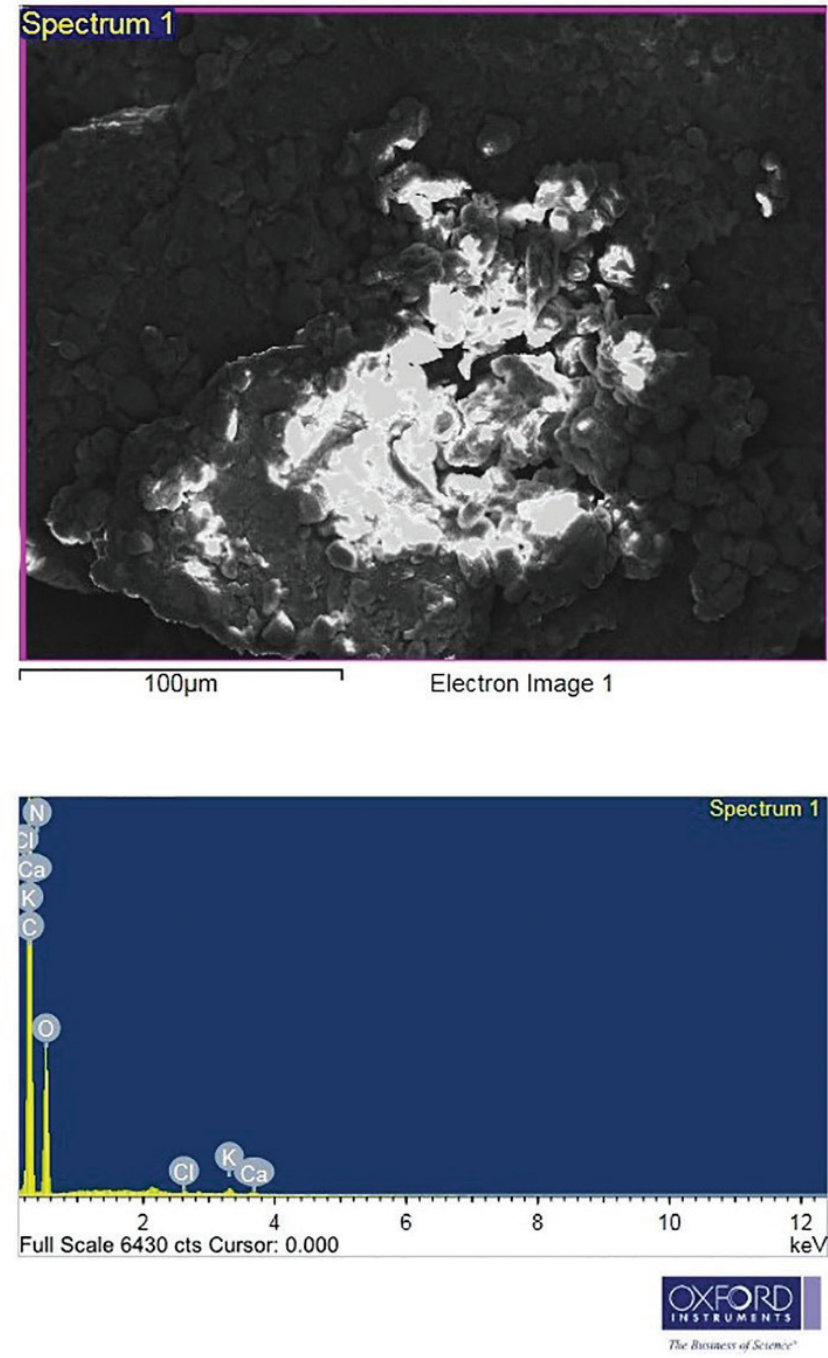

Figure 3: SEM-EDX spectra for elemental analysis of $P$. campechiana leaf powder.

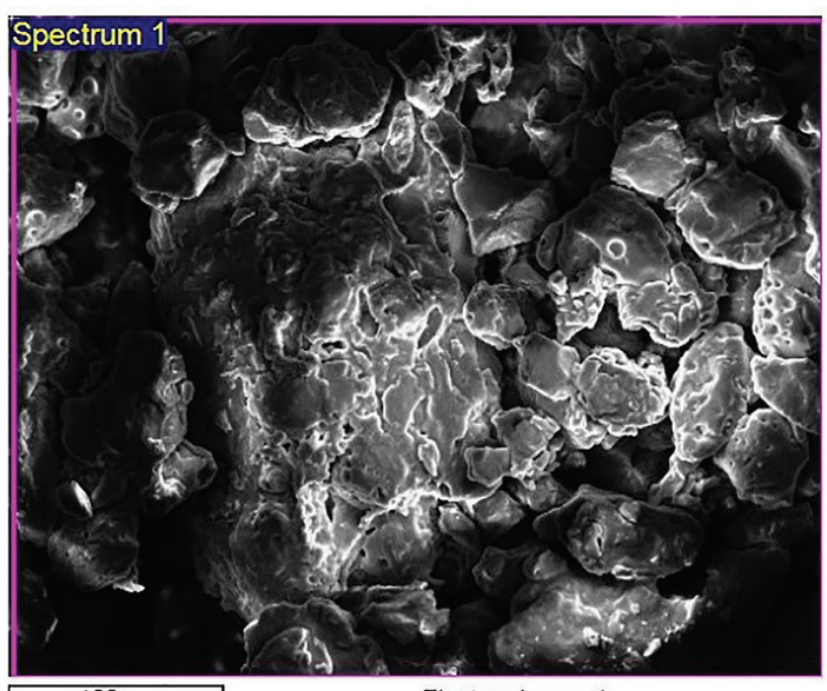

Electron Image 1

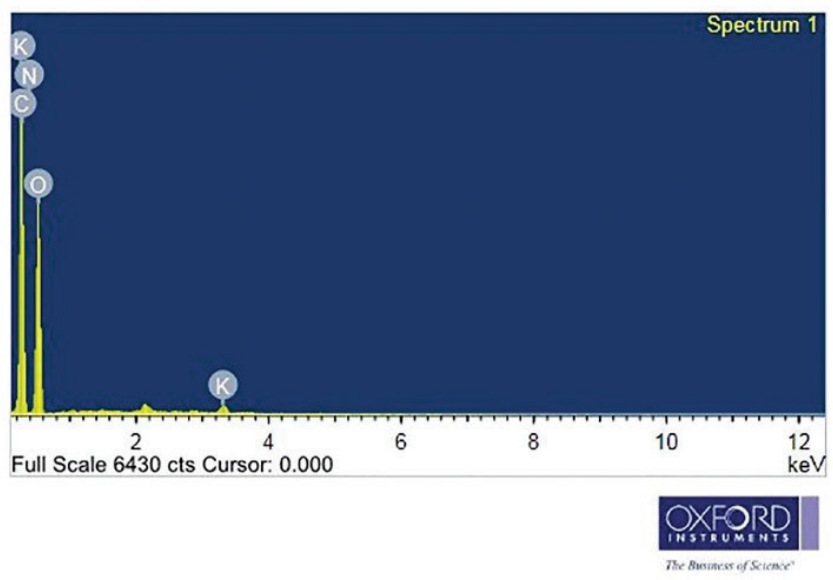

Figure 4: SEM-EDX spectra for elemental analysis of $P$. campechiana fruit powder.

Table 6: Elemental analysis of $P$. campechiana leaf and fruit.

\begin{tabular}{|c|c|c|c|c|}
\hline \multirow{3}{*}{ Elements } & \multicolumn{4}{|c|}{ Elemental composition (\%) } \\
\hline & \multicolumn{2}{|c|}{ P. campechiana leaf } & \multicolumn{2}{|c|}{ P. campechiana fruit } \\
\hline & Weight & Atomic & Weight & Atomic \\
\hline $\mathrm{N}$ & 2.29 & 7.23 & 1.21 & 3.19 \\
\hline $\mathrm{O}$ & 22.08 & 60.98 & 27.75 & 64.03 \\
\hline $\mathrm{Cl}$ & 0.21 & 0.27 & nd & nd \\
\hline K & 0.58 & 0.65 & 0.81 & 0.76 \\
\hline $\mathrm{Ca}$ & 0.28 & 0.31 & nd & nd \\
\hline C & 8.31 & 30.56 & 10.42 & 32.02 \\
\hline
\end{tabular}

compounds identified in this study, including N-(2-cyano-ethyl)N-methyl-acetamide, calendin, kaur-16-ene, dimethylamine, N-(Neopentyloxy), 2-pentene, 3-ethyl-4,4-dimethyl-, 5-keto2,2-dimethylheptanimine, N, N-dimethyl-O-(1-methyl-butyl)hydroxylamine, $\beta$-D-Glucopyranoside, methyl, were not assessed in a specific manner.
The SEM-EDX spectra and elemental compositions were also analyzed. The leaf powder showed the presence of various elements, such as $\mathrm{N}, \mathrm{O}, \mathrm{Cl}, \mathrm{K}, \mathrm{Ca}$, and $\mathrm{C}$, in which $\mathrm{O}$ was in the highest percentage followed by $\mathrm{C}$, while small quantities of $\mathrm{N}$, $\mathrm{Cl}, \mathrm{K}$, and $\mathrm{Ca}$ were also detected. Similarly, N, O, K, and C were detected in $P$. campechiana fruit powder, in which $\mathrm{O}$ was found in 
highest percentage followed by $\mathrm{C}$, while small amounts of $\mathrm{N}$ and $\mathrm{K}$ were also present in fruit powder of $P$. campechiana.

\section{CONCLUSION}

The physicochemical and phytochemical analyses focused on in this study can be used for the standardization and the identifying parameters to validate the drug. The results revealed the presence of medicinally significant constituents in the plant. The GC-MS analysis was carried out for identifying the phytoconstituents and to study the nature of active principles of those phytoconstituents. Therefore, it can be concluded that the methanolic extracts of $P$. campechiana leaves and fruits can be seen as a good source of useful drugs. Hence, further studies on this plant are proposed for the development of novel drugs.

\section{ACKNOWLEDGMENTS}

The authors delicately acknowledge the Department of Biosciences, Mangalore University, for providing DST-FIST and UGC-SAP supported laboratory facilities and also acknowledge DST-PURSE laboratory, Mangalore University. The authors are grateful to the Council of Scientific and Industrial Research-University Grants Commission (CSIR-UGC) fellowship, New Delhi, for providing financial support to carry out this study.

\section{CONFLICTS OF INTEREST}

Authors declared that there are no conflicts of interest.

\section{REFERENCES}

[1] Seow LJ, Beh HK, Sadikun A, Asmawi MZ. Preliminary phytochemical and physicochemical characterization of Gynura segetum (Lour) Merr (Compositae) leaf. Trop J Pharm Res 2013;12(5):777-82.

[2] Sudha A, Srinivasan P. Physicochemical and phytochemical profiles of aerial parts of Lippia nodiflora L. Int J Pharm Sci Res 2013;4(11):4263-71.

[3] Aslam F, Rehman KU, Asghar M, Sarwar M. Antibacterial activity of various phytoconstituents of neem. Pak J Agric Sci 2009;46(3):20913

[4] Chan-Zapata I, Canul-Canche J, Fernández-Martín K, Martín-Quintal $\mathrm{Z}$, Torres-Romero JC, Lara-Riegos JC, et al. Immunomodulatory effects of the methanolic extract from Pouteria campechiana leaves in macrophage functions. Food Agr Immunol 2018;29(1):386-99.

[5] Ma J, Yang H, Basile MJ, Kennelly EJ. Analysis of polyphenolic antioxidants from the fruits of three Pouteria Species by selected ion monitoring liquid chromatography-mass spectrometry. J Agr Food Chem 2004;52:5873-8.

[6] Aseervatham GSB, Sivasudha T, Sasikumar JM, Christabel PH, Jeyadevi R, Ananth DA. Antioxidant and hepatoprotective potential of Pouteria campechiana on acetaminophen-induced hepatic toxicity in rats. J Physiol Biochem 2014;70:1-14.

[7] Indian Pharmacopoeia. Ministry of health and family welfare. Government of India, New Delhi, India, 1996.

[8] Chase CR, Pratt RJ. Fluorescence of powdered vegetable drugs with particular reference to development of a system of identification. J Am Pharm Assoc 1949;38:324-31
[9] Harborne JB. Phytochemical methods. Chapman and Hall Ltd., London, UK, pp 49-188, .

[10] Trease GE, Evans WC. Pharmacognosy. 13th edition, ELBS/Bailliere Tindall, London, UK, pp 345-6, 535-6, 772-3, .

[11] Sofowora A. Medicinal plants and traditional medicine in Africa. Spectrum Books Ltd, Ibadan, Nigeria, p 289,

[12] Nanna RS, Banala M, Pamulaparthi A, Kurra A, Kagithoju S. Evaluation of phytochemicals and fluorescent analysis of seed and leaf extracts of Cajanus cajan L. Int J Pharm Sci Rev Res 2013;22(1):11.

[13] Ramamurthy V, Sathiyadevi M, Thirumeni S. Preliminary phytochemical screening of methanol extract of Indigo feratrita Linn. Int J Adv Res Sci Eng Technol 2017;4(11):4854-60.

[14] Sahu R, Saxena J. Screening of total phenolic and flavonoid content in conventional and non-conventional species of curcuma. J Pharmacogn Phytochem 2013;2(1):176-9.

[15] Fahal EM, Rani AMB, Aklakur MD, Chanu TI, Saharan N. Quanlitative and quantitative phytochemical analysis of Moringa oleifera (Lam) Pods. Int J Curr Microbiol Appl Sci 2018;7(5):657-65.

[16] Chandran KCI, Indira G. Quantitative estimation of total phenolic, flavonoids, tannin and chlorophyll content of leaves of Strobilanthes Kunthiana (Neelakurinji). J Med Plants Stud 2016;4(4):282-6.

[17] Selvi SV, Basker A. Phytochemical analysis and GC-MS profiling in the leaves of Sauropus Androgynus (1) MERR. Int J Drug Dev Res 2012;4(1):162-7.

[18] Nagani KV, Kevalia J, Chanda SV. Pharmacognostical and phytochemical evaluation of stem of Cissus Quadrangularis L. IJPSR. 2011;2(11):2856-62.

[19] Chumbhale DS, Upasani CD, Pharmacognostic standardization of stems of Thespesia lampas (Cav.) Dalz and Gibs. Asian Pac J Trop Biomed 2012;2(5):357-63.

[20] Rakholiya K, Kaneria M, Chanda S. Physicochemical and hytochemical analysis of different parts of Indian Kesar Mango-a unique variety from Saurashtra region of Gujarat. Pharmacogn J. 2016;8(5):502-6.

[21] Sujatha S, Anand S, Sangeetha KN, Shilpa K, Lakshmi J, Balakrishnan A, et al. Biological evaluation of (3b)-STIGMAST-5-EN-3-OL as potent anti-diabetic agent in regulating glucose transport using in vitro model. Int J Diabetes Mellit 2010;2(2):101-9.

[22] Belakhdar G, Benjouad A, Abdennebi EH. Determination of some bioactive chemical constituents from Thesium humile Vahl. J Mater Environ Sci 2015;6(10):2778-83.

[23] Ghosh G, Panda P, Rath M, Pal A, Sharma T, Das D. GC-MS analysis of bioactive compounds in the methanol extract of Clerodendrum viscosum leaves. Pharmacognosy Res 2015;7(1):110-13.

How to cite this article:

Pai A, Shenoy C. Physicochemical, phytochemical, and GC-MS analysis of leaf and fruit of Pouteria campechiana (Kunth) Baehni. J Appl Biol Biotech 2020; 8(04):090-097. DOI: 10.7324/JABB.2020.80414 